\title{
TUTORIAL PENGGUNAAN SOFTWARE SMS 11.1 MODUL RMA2 UNTUK MENGANALISA POLA PERGERAKAN ARUS DI PELABUHAN BELAWAN
}

\author{
Rizky Franchitika \\ Dosen Fakultas Teknik Sipil dan Perencanaan Institut Teknologi Medan \\ (Rizky.franchitika@gmail.com)
}

Diterima $\quad$ : 31 Maret 2017

Disetujui : : 11 Mei 2017

\begin{abstract}
ABSTRAK
Pelabuhan Belawan merupakan pelabuhan terbesar di Sumatera dan ketiga terbesar di Indonesia setelah Tanjung Priok dan Tanjung Perak. Pelabuhan Belawan berada didaratan semenanjung diantara Sungai Belawan dan Sungai Deli. Modelisasi pada pola arus di Pelabuhan Belawan akan menemui masalah yang sangat kompleks, karena geometri daerah pantai yang tidak beraturan adalah bagian sungai yang berhubungan langsung dengan laut. Pengaruh pasang surut terhadap sirkulasi kecepatan pola arus dan debit sungai yang masuk ke Pelabuhan Belawan sangat besar. Salah satu model matematik untuk pemecahan masalah diatas adalah melakukan kajian dengan menggunakan software SMS (Surface-Water Modeling System) versi 11.1 pada modul RMA2, untuk mengetahui elevasi muka air pada titik di hulu dan hilir pelabuhan pada saat spring tide dan neap tide di musim basah (November) dan musim kering (Juli). Berdasarkan hasil yang didapatkan, kecepatan arus saat pasang tertinggi di musim basah adalah 0,04367 m/s - 0,4608 m/s, kecepatan arus saat pasang terendah di musim tersebut adalah berkisar antara $0,00028 \mathrm{~m} / \mathrm{s}-0,00287 \mathrm{~m} / \mathrm{s}$. Sedangkan kecepatan arus saat pasang tertinggi pada musim kering adalah $0,0229 \mathrm{~m} / \mathrm{s}-0,2744 \mathrm{~m} / \mathrm{s}$ dan kecepatan arus saat pasang terendah adalah $0,0003 \mathrm{~m} / \mathrm{s}-0,0019 \mathrm{~m} / \mathrm{s}$. Kecepatan arus pada musim basah cenderung lebih besar daripada musim kering, disebabkan karena pengaruh pasang surut dan debit yang besar, meskipun pada simulasi angin dianggap konstan, tidak menutup kemungkinan bahwa pengaruh tekanan angin pada pelabuhan mempengaruhi kecepatan aliran.
\end{abstract}

Kata Kunci : Eddy Viscosities, Pelabuhan Belawan, Pola Aliran, SMS v11.1

\section{ABSTRACT}

Belawan Port is the largest port in Sumatra and the third largest in Indonesia's after the Tanjung Priok and Tanjung Perak. Belawan Port is located in mainland peninsula between Belawan and Deli river. The modeling of flow pattern in Belawan Port will encounter a very complex problem, because of the irregular geometry of coastal area which is directly connected to the sea. Tidal influence on flow circulation and the river discharge into Belawan Port is very significant. One of the mathematical models to solve the above problem is aimed to study the use of SMS software (Surface-Water Modeling System) version 11.1 on RMA2 module, to determine the water level at port including upstream and downstream during spring tide and neap tide on the wet season (November) and the dry season (July). Based on the obtained results, the flow velocity of the highest tide on the wet season is $0.04367 \mathrm{~m} / \mathrm{s}-0.4608 \mathrm{~m} / \mathrm{s}$, the flow velocity of the lowest tide on the dry season is between 0.00028 $\mathrm{m} / \mathrm{s}$ and $0.00287 \mathrm{~m} \mathrm{~s}$. While the flow velocity of the highest tides on the dry season is $0.0229 \mathrm{~m} / \mathrm{s}-0.2744 \mathrm{~m} / \mathrm{s}$ and low tide flow velocity is $0.0003 \mathrm{~m} / \mathrm{s}-0.0019 \mathrm{~m} / \mathrm{s}$. Flow velocity on the wet season tends to be larger than the 


\section{Ricky Franchitika}

dry season due to the influence of tide and large discharge. Although the wind is considered constant on this simulation, it is possible that the wind pressure against the port affects the flow velocity.

Keywords: Belawan Port, Eddy Viscosities, Flow Pattern, SMS v11.1

\section{Pendahuluan}

Pelabuhan Belawan berada di timur laut pantai Sumatera yang memiliki luas wilayah berkisar antara $\pm 27 \mathrm{~km}^{2}$, terletak di muara sungai Belawan. Pelabuhan Belawan merupakan pelabuhan terbesar ketiga di Indonesia setelah Tanjung Priok dan Tanjung Perak. Dari Selat Malaka ke pelabuhan tersebut dihubungkan oleh suatu alur pelayaran sejauh $\pm 12 \mathrm{~km}$ dengan lebar alur $100 \mathrm{~m}$ dan kedalaman -9,50 MLWS sampai dengan -10 MLWS, sedangkan kedalaman kolam pelabuhan adalah -6,0 sampai -11,5 MLWS.

Selain itu, topografi muka air laut juga turut mempengaruhi gerakan arus permukaan.Ditinjau dari letak wilayahnya yang berada pada 2 muara Sungai Belawan dan Sungai Deli. Pergerakan massa air atau dikenal dengan arus, merupakan fenomena yang sangat kompleks. Hal ini berkaitan dengan besarnya variasi dari faktor-faktor pengontrol terjadinya arus di perairan (Davis, 1972). Namun demikian, pemahaman tentang arus di perairan adalah hal yang sangat penting dalam kaitannya dengan kegiatan pemanfaatan dan pengelolaan.

\section{Tinjauan Pustaka}

\subsection{Pelabuhan Belawan}

Pengenalan lokasi penelitian yaitu Pelabuhan Belawan dan Kolam Citra, Sumatera Utara, sangat penting kaitannya sebelum data dikumpulkan untuk kemudian diolah dan dianalisis sebagai usaha penanganan permasalahan sedimentasi di Pelabuhan tersebut.

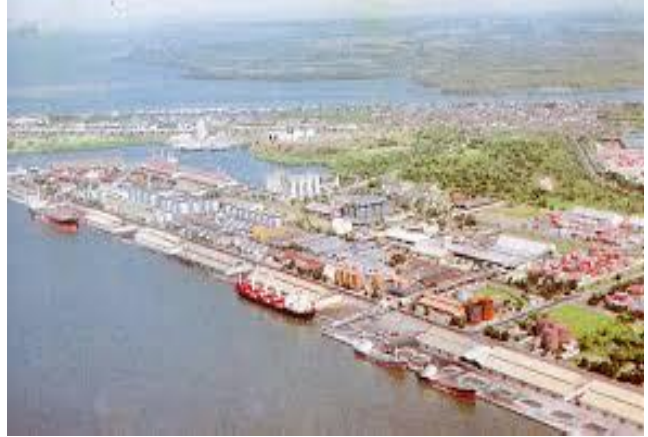

\section{Gambar 1 Pelabuhan Belawan dari sisi Sungai Belawan}

\subsection{SMS (Surface-water Modeling System)}

SMS (Surface-water Modeling System) adalah sofware program yang cukup lengkap untuk membuat dan mensimulasikan surface water model. Program ini didesain untuk perhitungan secara model numerik untuk sungai, pantai, teluk, dan danau.

\subsection{Pemodelan Arus (RMA2)}

Model matematik yang akan digunakan untuk kajian model arus di Pelabuhan Belawan adalah RMA2 (Resource Management Associates) dari Waterways Experiment Station. Persamaan kontinuitas untuk aliran dua dimensi rata-rata kedalaman (averaged continuity equation) dapat dituliskan sebagai berikut:

$\frac{\partial h}{\partial t}+h\left(\frac{\partial u}{\partial x}+\frac{\partial u}{\partial x}\right)+u \frac{\partial u}{\partial x}+v \frac{\partial v}{\partial y}=0$

Persamaan momentum pada arah sumbu $x$ dan y untuk aliran dua dimensi rata-rata kedalaman dapat dituliskan sebagai berikut:

Untuk aliran arah sumbu x, 
$\frac{\partial u}{\partial t}+u \frac{\partial u}{\partial x}+v \frac{\partial u}{\partial y}+g\left(\frac{\partial h}{\partial x}+\frac{\partial a_{0}}{\partial x}\right)-\frac{\varepsilon_{x x}}{\rho} \frac{\partial^{2} u}{\partial x^{2}}-\frac{\varepsilon_{x y}}{\rho} \frac{\partial^{2} u}{\partial y^{2}}$

$+\frac{g u}{C^{2} h} \sqrt{u^{2}+v^{2}}=0$

Untuk aliran arah sumbu y,

$$
\begin{aligned}
& \frac{\partial v}{\partial t}+u \frac{\partial v}{\partial x}+v \frac{\partial v}{\partial y}+g\left(\frac{\partial h}{\partial y}+\frac{\partial a_{0}}{\partial y}\right)-\frac{\varepsilon_{x x}}{\rho} \frac{\partial^{2} v}{\partial x^{2}} \\
& -\frac{\varepsilon_{x x}}{\rho} \frac{\partial^{2} v}{\partial x^{2}}-\frac{\varepsilon_{y y}}{\rho} \frac{\partial^{2} v}{\partial y^{2}}+\frac{g v}{C^{2} h} \sqrt{u^{2}+v^{2}}=0 \ldots \ldots \ldots . .(3)
\end{aligned}
$$

Keterangan:

$$
\begin{array}{ll}
u & : \text { Kecepatan horisontal aliran arah } \mathrm{x} \\
v & : \text { Kecepatan horisontal arah } \mathrm{y} \\
t & : \text { Fungsi waktu } \\
g & : \text { Percepatan gravitasi } \\
h & : \text { Kedalaman air } \\
a_{0} & : \text { Elevasi dari dasar tampang } \\
\rho & : \text { Kassa jenis } \\
\varepsilon_{x x} & : \text { Koefisien pertukaran turbulensi normal } \\
& \text { arah } \mathrm{x} \\
\varepsilon_{x y} & : \text { Koefisien pertukaran turbulensi } \\
& \text { tangensial arah } \mathrm{x} \\
\varepsilon_{y x} & : \text { Koefisien pertukaran turbulensi } \\
& \text { tangensial arah y } \\
\varepsilon_{y y} & : \text { Koefisien pertukaran turbulensi normal } \\
& \text { arah y } \\
C & : \text { Koefisien kekasaran Chezy (atau koef. } \\
& \text { Manning, } \mathrm{n}=1 / \mathrm{C} \mathrm{h}^{1 / 6}
\end{array}
$$

Data yang digunakan untuk pemodelan aliran sungai dengan RMA2 adalah sebagai berikut:

a. Data layout geometri saluran,

b. kontur elevasi dasar saluran atau data tampang saluran,

c. material dasar saluran digunakan untuk menentukan angka koefisien manning,

d. data debit sungai, untuk keperluan perencanaan kapasitas saluran diperlukan data debit rancangan (debit banjir),

e. kondisi batas hilir muara berupa pasang surut air laut,

parameter hidraulik, meliputi koefisien kekasaran dasar sungai, koefisien difusi aliran, dan konsentrasi sedimen. Data ini diperoleh melalui proses kalibrasi model atau data sekunder dari studi sejenis.

\subsection{Kondisi Umum Pelabuhan Belawan}

Area Pelabuhan Belawan dimulai dari daerah Tanjung Betung Camar di utara dan memanjang mengikuti garis pantai hingga muara Sungai Belawan dan Sungai Deli.

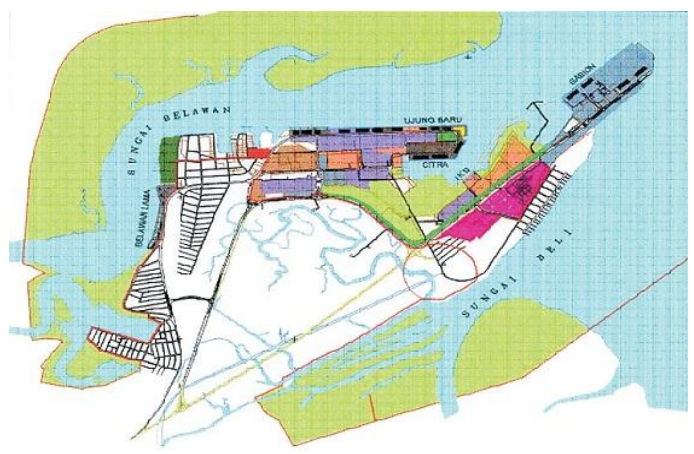

Gambar 2 Kondisi eksisting Belawan

\subsection{Alat Penelitian}

Program SMS (Surface-water Modeling System) versi 11.1. memakai kebutuhan minimal untuk spesifikasi komputer sebagai berikut:

a. RAM 512 MB (direkomendasikan 2 GB) untuk Windows XP, RAM 1 GB (direkomendasikan 4 GB) untuk Windows Vista 7,8,

b. processor disarankan memiliki lebih dari 1 core,

c. graphics card disarankan tipe dedicated atau terpisah dari processor dengan Open GL 1,5 atau diatasnya,

display resolution yang digunakan adalah $1024 \times 768$ atau diatasnya.

\subsection{Pemodelan \\ Input Data Topografi}

Tahapan awal penelitian ini dilakukan data topografi. Untuk mendapatkan digitasi yang akurat, terlebih dahulu koordinat peta diikat dengan Global Mapper. Lalu digitasi dilanjutkan dengan menggunakan software Autocad Land Desktop (ALD).

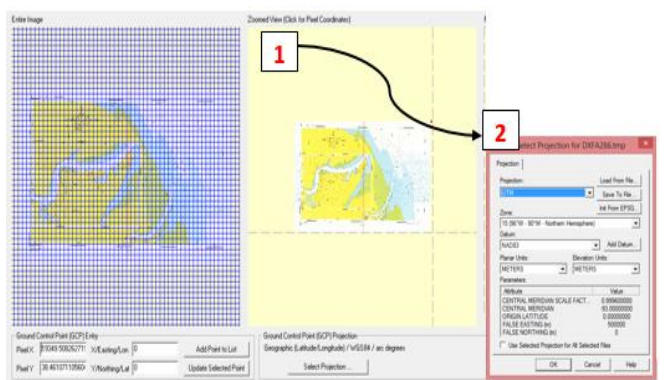

Gambar 4 Proses pengikatan titik koordinat dari jpeg ke global mapper 


\section{Ricky Franchitika}

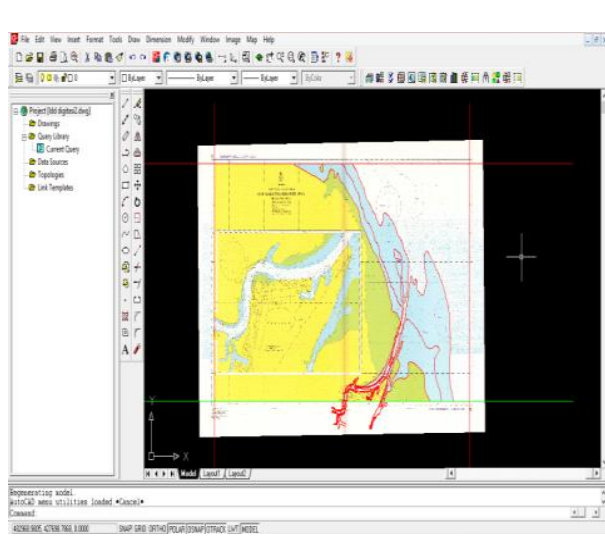

Gambar 5 Bentuk peta layout pelabuhan yang telah didigitasi dengan menggunakan ALD

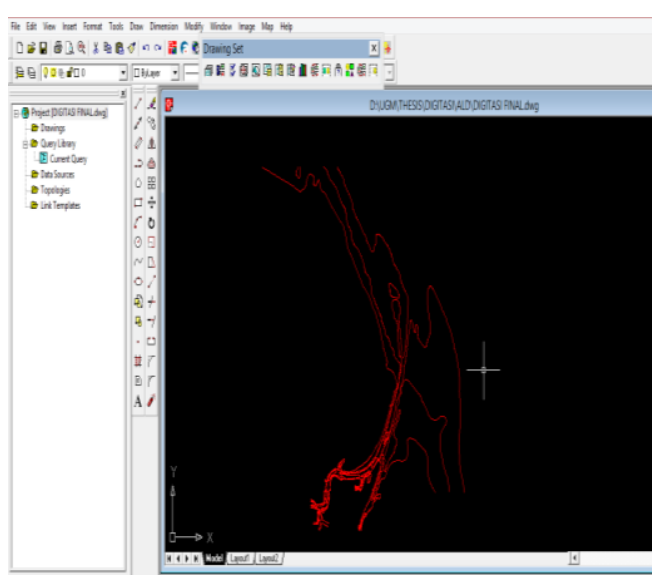

Gambar 6 Bentuk peta layout pelabuhan yang telah didigitasi

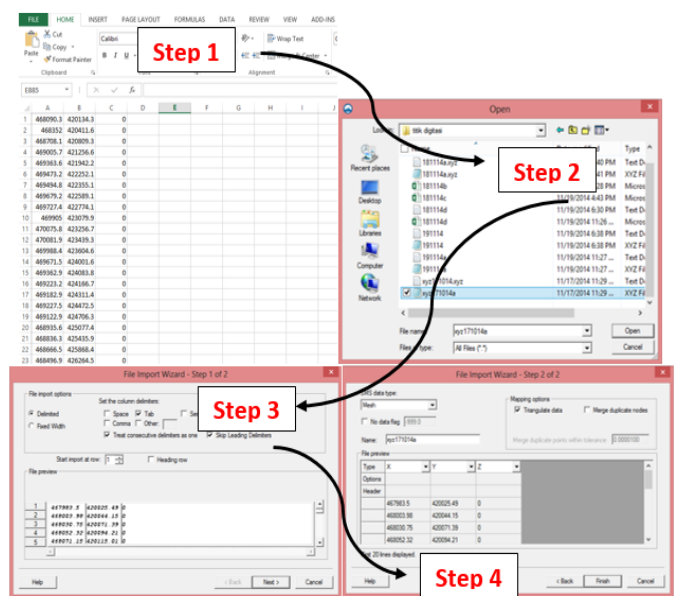

Gambar 7 Proses memasukkan titik digitasi yang diperoleh dari ALD Ke SMS

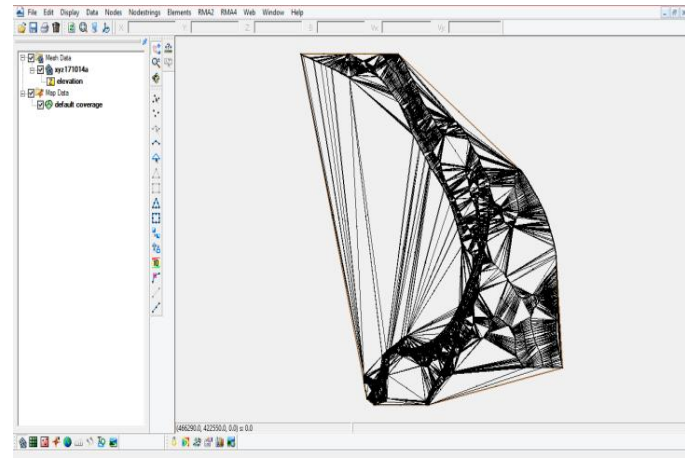

Gambar 8 Bentuk jaring elemen yang telah didigitasi dari ALD ke SMS

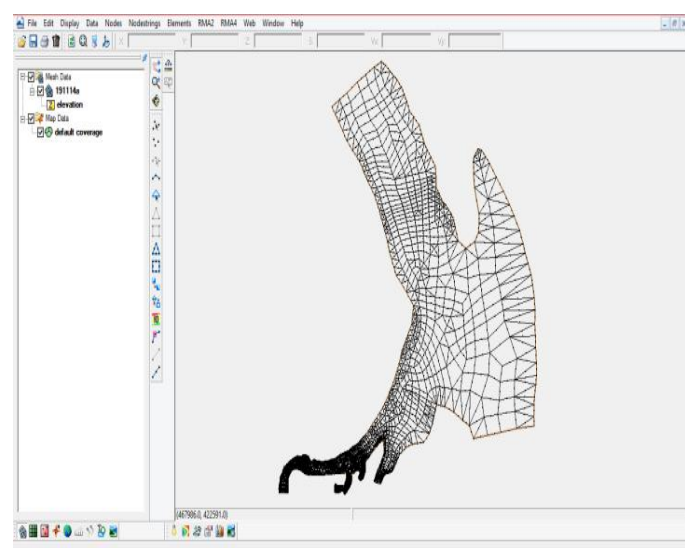

Gambar 10 Bentuk jaring elemen yang akan dimodelkan

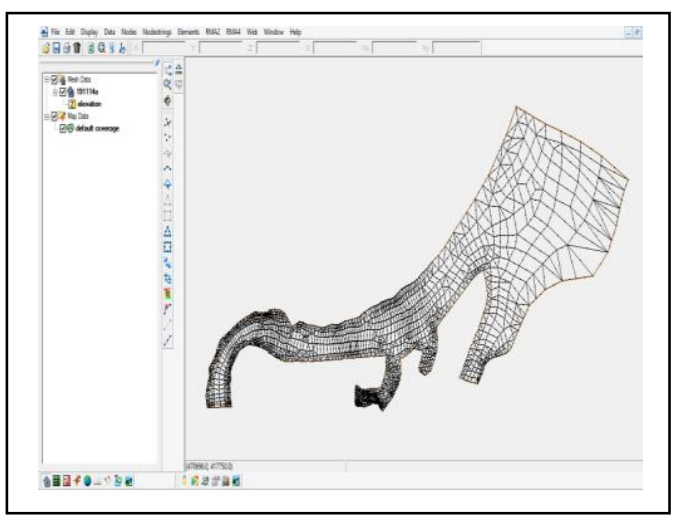

Gambar 10 Bentuk jaring elemen yang akan disimulasikan 
2.7 Input Data Pasut dan Proses Simulasi

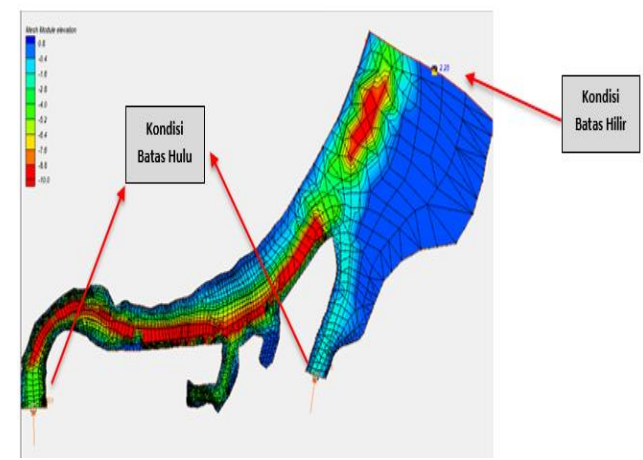

Gambar 11 Bentuk layout dengan kondisi Batas

Pada proses running RMA2 diperlukan beberapa input, dan sebelum memasukkan input tersebut terdapat beberapa proses yang perlu dilakukan diantaranya adalah sebagai berikut:

- Tiap project file mesh data perlu menambahkan boundary condition. Untuk input perlu diberi garis nodestring dan memasukkan angka debit dan pasang surut pada assign boundary condition.

- Untuk input pasang surut pilih water surface elevation lalu pilih transient.

- Sebelumnya isi dan dipilih komponen properties pada RMA2 model control dan RMA2 material properties.

\section{Hasil dan Pembahasan}

Penelitian ini akan memaparkan hasil simulasi pola arus yang terjadi pada Pelabuhan Belawan. Seperti yang telah dijelaskan diatas, pelabuhan memiliki 1 aliran sungai yang masuk (inflow) yaitu Sungai Belawan. Outflow pada pemodelan ini menggunakan tinggi elevasi pasang surut muka air pada titik alur pelabuhan untuk mengikuti persamaan kontinuitas debit yang masuk dan keluar pelabuhan. Simulasi aliran akan dilakukan pada saat musim basah maksimum dan musim kering maksimum.

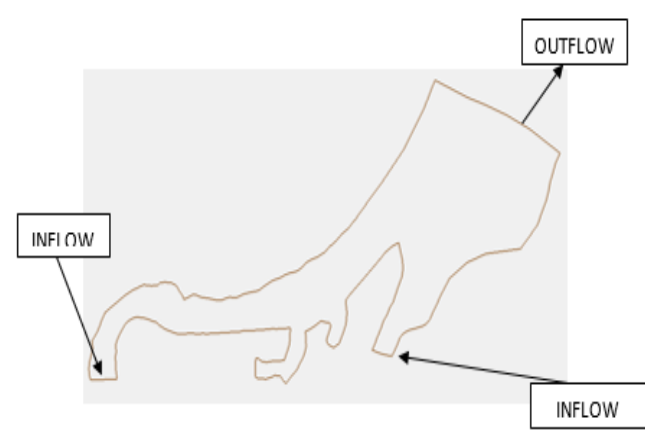

Gambar 12 Skema aliran masuk dan keluar pelabuhan

\subsection{Hidrooseanografi}

a. Pasang Surut

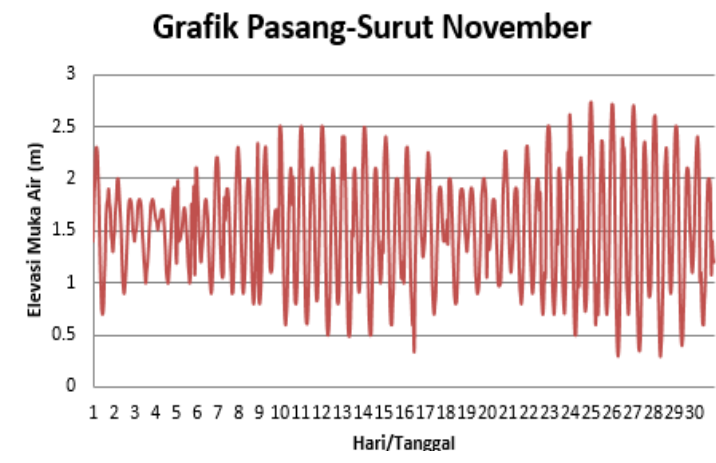

Gambar 13 Grafik pasang surut November

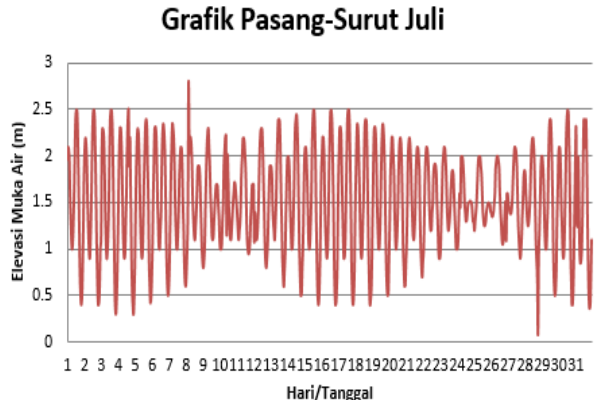

Gambar 14 Grafik pasang surut Juli

\section{b. Angin}

Angin dominan adalah angin muson timur-laut yang bertiup sepanjang bulan November hingga bulan Maret. Sedangkan angin munson barat daya bertiup dari Juni hingga September dengan kekuatan rata-rata di Selat Malaka 10 knots. 


\section{c. Gelombang}

Gelombang yang terjadi di sepanjang garis pantai Belawan berasal dari gelombang laut dalam dari arah utara ke timur laut, yang dibangkitkan sesuai fetch di perairan Selat Malaka. Gelombang ini terjadi pada saat muson timur laut yang terjadi dari November hingga Maret. Gelombang ini merupakan gelombang signifikan yang merupakan penyebab utama terjadinya sedimentasi di pintu masuk alur pelayaran Belawan.

\subsection{Hasil Pembacaan Output Running Pemodelan Arus}

\subsubsection{Vektor aliran pada saat musim basah}

Simulasi aliran pada Pelabuhan Belawan dilakukan pada saat kondisi spring tide dan neap tide di musim penghujan atau musim basah dan diwakili pada bulan November pada kondisi ekstrim. Secara khusus angka elevasi rata-rata muka air saat purnama (spring), yaitu MHWS (Mean High Water Spring, rata-rata muka air tinggi saat purnama) dan MLWS (Mean Low Water Spring, rata-rata muka air rendah saat purnama) diperoleh dari merata-ratakan pasang tertinggi dan surut terendah setiap periode waktu purnama (pada umumnya terjadi satu kali dalam kurun waktu selama 15 hari). Pada tahapan ini, pembacaan hasil simulasi berupa perbandingan vektor aliran pada saat elevasi rata-rata muka air tertinggi dan elevasi rata-rata muka air terendah.

\section{a. Alur}

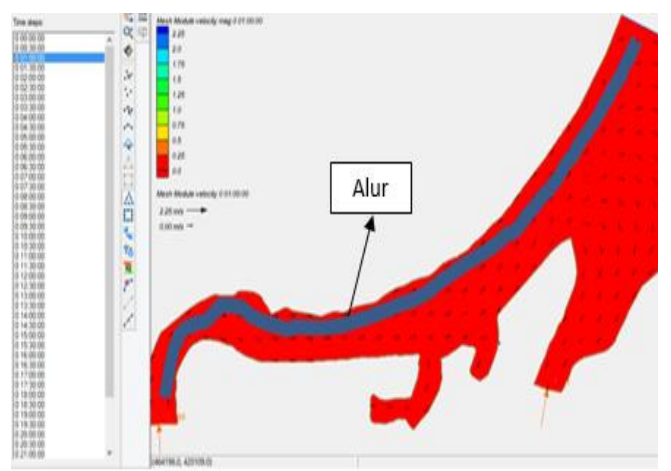

Gambar 15 Vektor aliran pada saat kondisi surut (01.00)

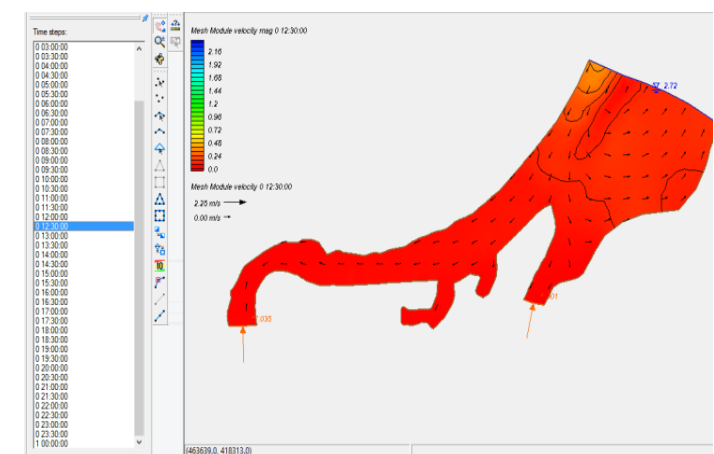

Gambar 16 Vektor aliran pada saat kondisi pasang (12.30)

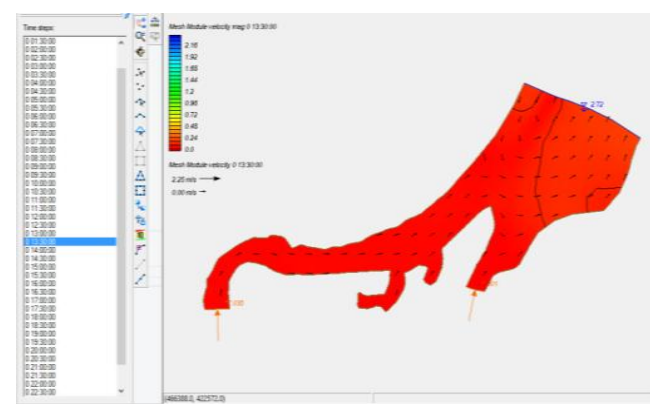

Gambar 17 Vektor aliran pada saat kondisi surut (13.30)

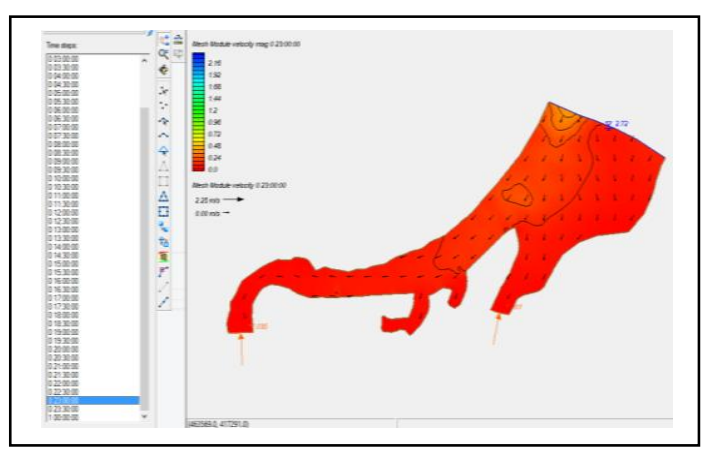

Gambar 18 Vektor aliran pada saat kondisi pasang (23.00)

Pada saat laut mengalami transisi dari surut ke pasang tertinggi (spring tide) kecepatan arusnya cenderung naik. Pada hasil dapat kita lihat pada saat laut mengalami transisi dari surut ke pasang kecepatan arusnya cenderung turun $0,00701 \mathrm{~m} / \mathrm{s}-0,00381 \mathrm{~m} / \mathrm{s}$. Kemudian kecepatan arus kembali naik pada pukul 12.30 (Gambar 16). Berdasarkan dari hasil yang didapat selama 24 jam, vektor aliran lebih 
cenderung sering menuju ke arah laut (hilir). Kecepatan arus pada saat pasang terendah adalah sekitar $0,04367 \mathrm{~m} / \mathrm{s}$, dan kecepatan arus pada saat pasang tertinggi adalah sekitar 0,4608 $\mathrm{m} / \mathrm{s}$. Berikut adalah gambar penempatan titik point yang akan diteliti kecepatan alirannya.

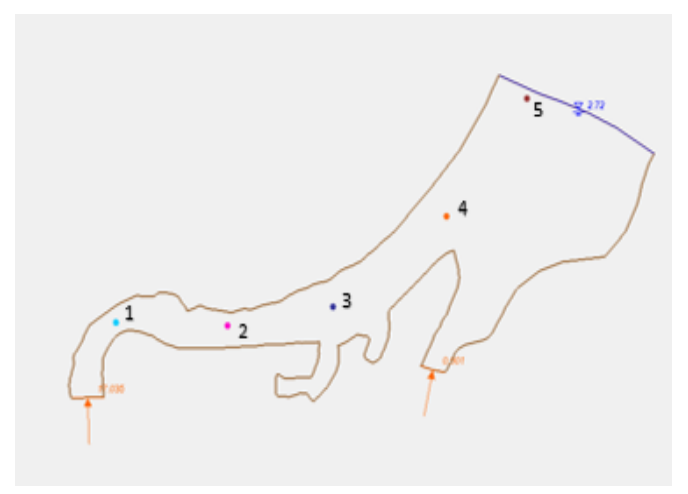

\section{Gambar 19 Titik point yang ditinjau kecepatan alirannya}

Berdasarkan dari hasil simulasi yang didapat, terlihat bahwa kecepatan arus maksimum terjadi pada titik point 5 yaitu $0,4608 \mathrm{~m} / \mathrm{s}$, dan kecepatan arus minimum terjadi pada titik point 1 yaitu $0,00028 \mathrm{~m} / \mathrm{s}$. Penyebabnya adalah karena pada point 5 nilai arus pasang surut yang tinggi dan debit yang tinggi.

\section{- Kolam Citra}

Pada saat pasang tertinggi, Kolam Citra memiliki arus sebesar $0,0505 \mathrm{~m} / \mathrm{s}$ dan pada saat surut terendah, Kolam Citra memiliki arus 0 $\mathrm{m} / \mathrm{s}$.

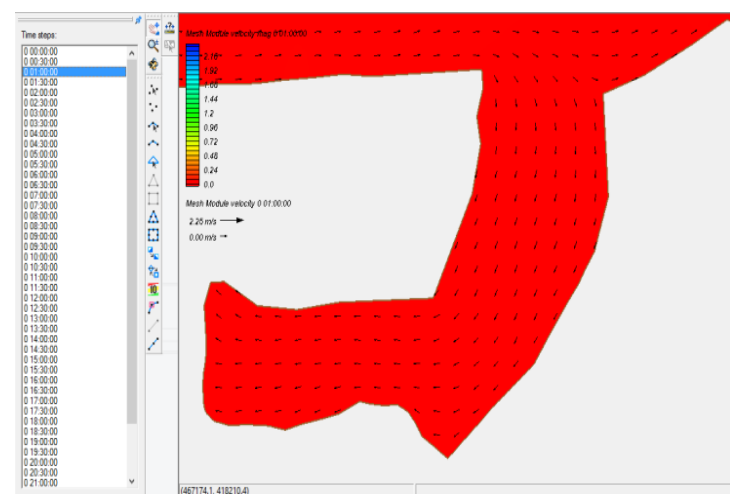

Gambar 20 Vektor aliran pada saat pasang tertinggi di Kolam Citra

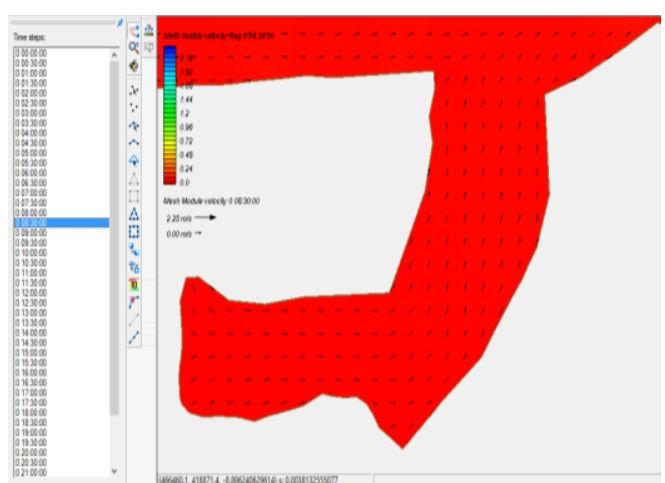

Gambar 21 Vektor aliran pada saat surut terendah di Kolam Citra

Berdasarkan dari data yang didapat, maka dapat disimpulkan bahwa nilai kecepatan arus pada saat transisi dari pasang ke surut atau sebaliknya cenderung mengalami penurunan dari nilai sebelumnya. Hal ini diakibatkan adanya perubahan arah yang terjadi pada saat itu, sehingga terjadi penurunan kecepatan arus.

\subsection{Vektor aliran pada saat musim kering}

Simulasi aliran kedua pada Pelabuhan Belawan dilakukan pada saat musim kering diwakili bulan Juli, dimana pasang terendah dan surut terendah terjadi pada bulan Juli. Running dilakukan selama 24 jam atau satu hari penuh dengan debit rerata sebesar $5,2387 \mathrm{~m}^{3} / \mathrm{s}$. Kecepatan aliran yang diteliti disesuaikan dengan parameter aliran pada hasil survey dan dimasukkan ke dalam simulasi RMA2.

- Alur

Debit rata-rata pada bulan Juli adalah sebesar $5,2387 \mathrm{~m}^{3} / \mathrm{s}$ dan elevasi muka air yang tertinggi pada bulan tersebut adalah sebesar $2,5 \mathrm{~m}$.

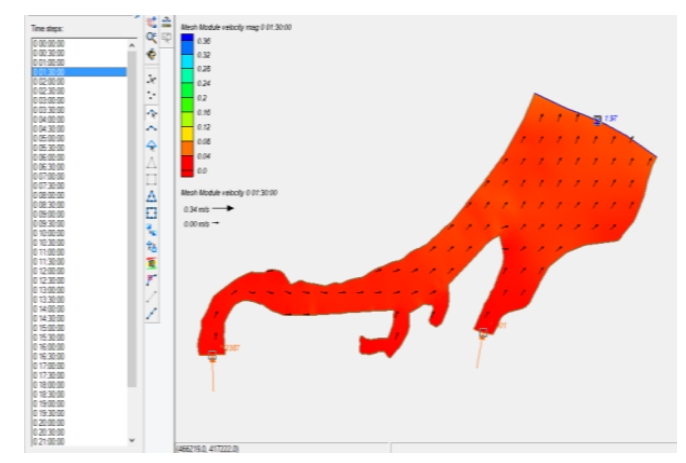

Gambar 22 Vektor aliran sewaktu air laut surut (Pukul 01.30 WIB) 
Pada Gambar 22 terlihat vektor aliran pada saat surut terendah sewaktu pukul 01.30 menuju ke arah hilir pelabuhan atau menuju ke alur pelabuhan dengan kecepatan arus pada point 1 adalah $0,0059 \mathrm{~m} / \mathrm{s}$. Kemudian muka air mengalami kenaikan pada saat pasang sekitar pukul 09.00 dengan kecepatan arus pada point 1 sebesar $0,0097 \mathrm{~m} / \mathrm{s}$.

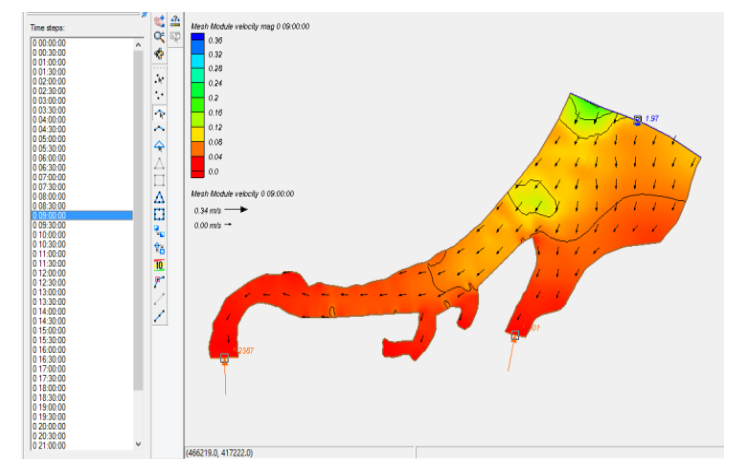

Gambar 23 Vektor aliran sewaktu air laut pasang (Pukul 09.00 WIB)

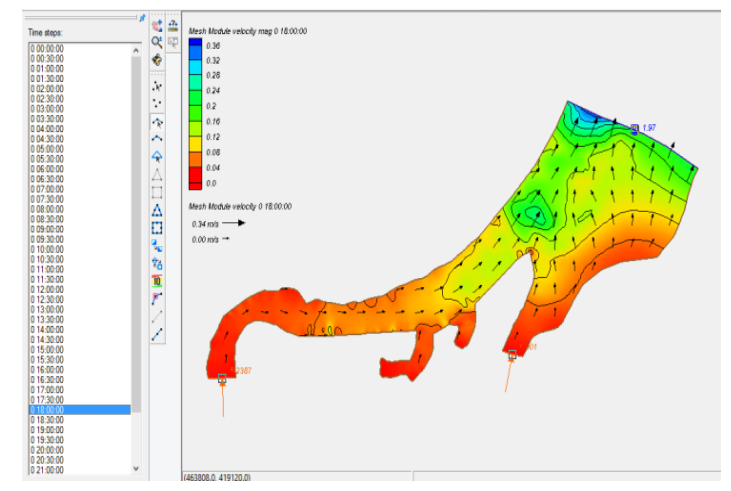

Gambar 24 Vektor aliran sewaktu air laut surut (Pukul 18.00 WIB)

Pada simulasi yang didapat terlihat bahwa kecepatan arus tertinggi ada pada point 1 yaitu 0,2774 m/s, dan kecepatan terendah ada pada point 1 juga yaitu sebesar $0,0003 \mathrm{~m} / \mathrm{s}$. Adanya perbedaan kecepatan arus antara point 1 dengan point lainnya karena disebabkan oleh nilai pasang surut yang terjadi pada bulan Juli tersebut dan adanya debit yang mengalir, dan parameter yang terinput di program RMA2.

\section{- Kolam Citra}

Pada Gambar 26 memperlihatkan vektor aliran pada saat pasang tertinggi dan Gambar 27adalah vektor aliran pada saat surut terendah di Kolam Citra pada bulan Juli. Pada saat pasang tertinggi, Kolam Citra memiliki arus sebesar $0,0333 \mathrm{~m} / \mathrm{s}$ dan pada saat surut terendah, kolam citra memiliki arus $0 \mathrm{~m} / \mathrm{s}$

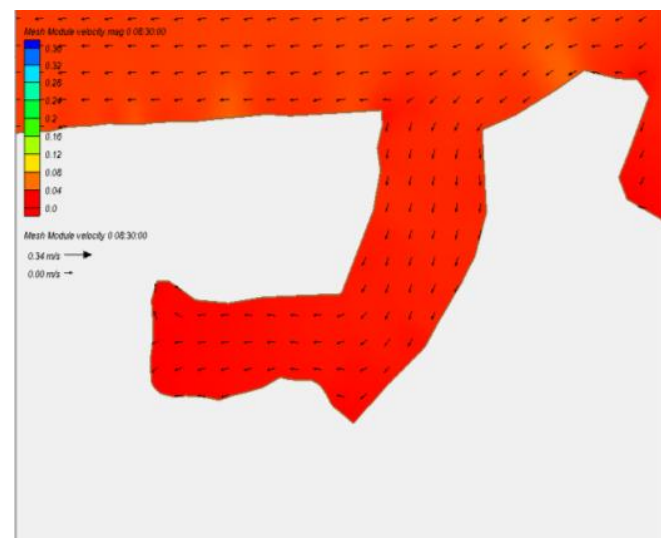

\section{Gambar 26 Vektor aliran pada saat pasang} tertinggi di Kolam Citra

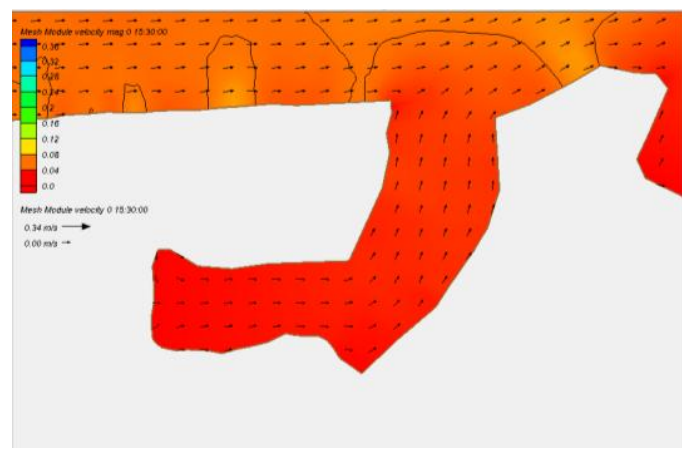

\section{Gambar 27 Vektor aliran pada saat surut terendah di Kolam Citra}

Berdasarkan dari data yang didapat, dapat disimpulkan bahwa nilai kecepatan arus pada saat transisi dari pasang ke surut atau sebaliknya cenderung mengalami penurunan dari nilai sebelumnya.

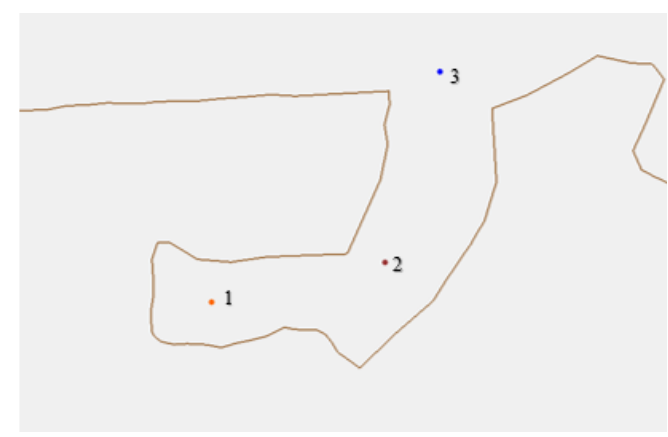




\section{Gambar 28 Titik point yang ditinjau pada Kolam Citra}

Pada simulasi didapatkan bahwa kecepatan arus tertinggi ada di point 3 yaitu sebesar $0,0333 \mathrm{~m} / \mathrm{s}$, dan kecepatan arus terendah ada di point 1 yang mencapai nilai 0 $\mathrm{m} / \mathrm{s}$.

Untuk indeks kerentanan pantai terhadap tunggang pasang dan surut, suatu pelabuhan aman terhadap pasang surut jika pasang dan surutnya tidak lebih dari $1,9 \mathrm{~m}$ dan suatu pelabuhan kerentanan pantai terhadap kecepatan arus maksimumnya tidak lebih dari $0,2 \mathrm{~m} / \mathrm{s}$ dan suatu pelabuhan rentan terhadap arus apabila kecepatan arus maksimumnya lebih besar dari $0,2 \mathrm{~m} / \mathrm{s}$.

Dari hasil simulasi yang di dapat, pengamatan kecepatan arus pada saat pasang tertinggi pada bulan Juli adalah berkisar antara $0,0003 \mathrm{~m} / \mathrm{s}-0,2744 \mathrm{~m} / \mathrm{s}$, dan kecepatan arus pada bulan November adalah berkisar antara $0,00028 \mathrm{~m} / \mathrm{s}-0,4608 \mathrm{~m} / \mathrm{s}$. Hal ini dapat disimpulkan bahwa kecepatan arus pada bulan Juli di Pelabuhan Belawan adalah normal, namun pada kecepatan arus pada bulan November di Pelabuhan Belawan melebihi batas normal, hal ini dikarenakan debit dan pasang surut yang lebih besar dibandingkan input nilai di bulan Juli. Hasil simulasi menunjukkan bahwa nilai kecepatan aliran pada saat musim basah atau di bulan November cenderung lebih tinggi dibandingkan dengan saat musim kering di bulan Juli.

\section{- Film loop}

Film loop adalah pembacaan informasi dengan mengubah output hasil running RMA2 menjadi tampilan video yang menunjukkan pergerakan muka air yang dapat berupa tampilan warna yang menunjukkan elevasi muka air ataupun bisa berupa vektor yang berbentuk anak panah yang mengarah sesuai arah aliran.

Untuk dapat membuat tampilan video dengan menggunakan film loop, cara pertama yang dilakukan adalah melakukan zoom atau memperbesar tampilan daerah yang akan ditinjau pada window. Hal tersebut dilakukan karena pada proses pembuatan film loop, tampilan yang terlihat pada window menyesuaikan hasil zoom. Kemudian pilih menu data lalu pilih film loop. Pada tab dialog film loop setup - general actionyang terbuka setelahnya.

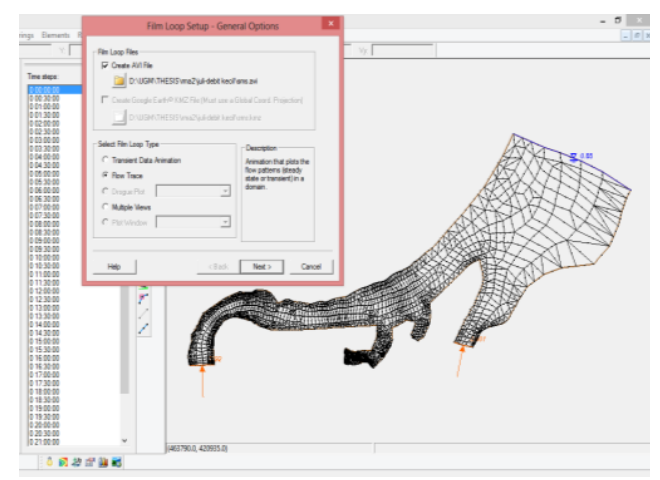

Gambar 29 Tab perintah film loop setupgeneral options

Pada pilihan yang ada di film loop type, pilih salah satu dari pilihan diantaranya transient data animation, merupakan tipe film loop yang menunjukkan perubahan elevasi muka air sesuai perubahan waktu dengan perubahan warna tergantung elevasinya. Bisa memilih tipe flow trace yang merupakan tipe film loop untuk menunjukkan arah aliran dengan anak panah kecil yang bergerak sesuai perubahan waktu. Setelah memilih tipe film loop yang diinginkan kemudian pilih next dan muncul dialog box selanjutnya yaitu film loopsetup - time setup.

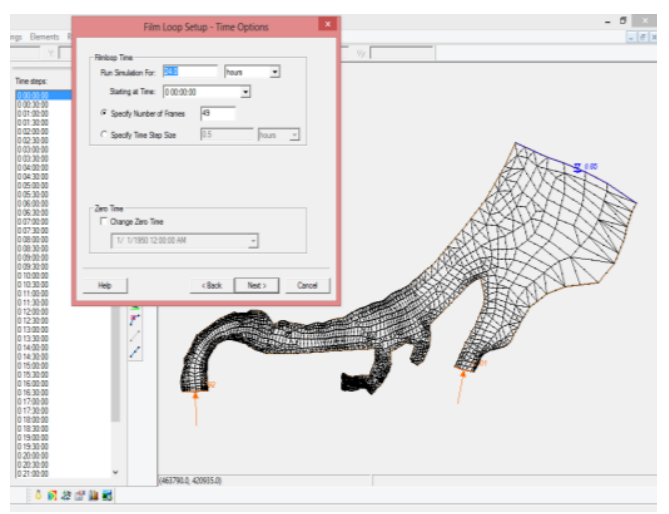

\section{Gambar 30 Tab dialog film loop setup-time options}

Pada dialog box tersebut diatur jam data yang akan dibuat film loop dan mulai dari waktu yang diinginkan, serta pengaturan frame yang ingin digunakan dalam jangka waktu tertentu. Khusus untuk pilihan flow trace setelah 
time setup yang muncul selanjutnya adalah dialog box film loop setup - flow trace option. Pada penelitian ini pilihan tersebut memakai nilai default. Setelah itu dialog box selanjutnya untuk kedua tipe adalah film loop setup - display options, merupakan pilihan mengenai kualitas video, semakin bagus kualitas video semakin bagus pula proses rendering video. Setelah semua options selesai lalu klik finish dan proses rendering dimulai seperti Gambar 31. Output dari film loop tersebut berupa video yang dapat di pause, stop atau diatur waktu prosesnya agar dapat dilihat perilaku arus aliran yang terjadi pada pelabuhan.

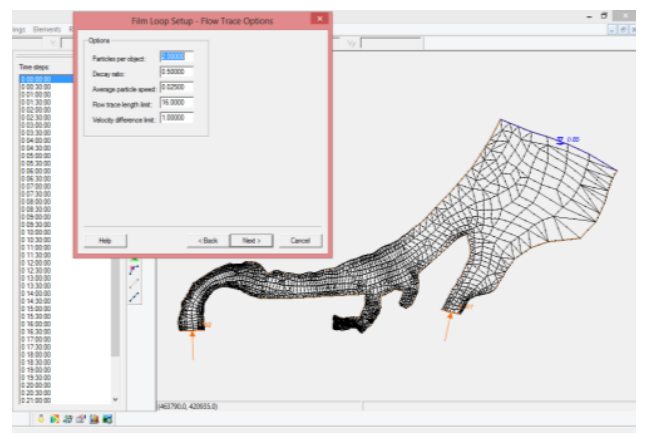

\section{Gambar 31 Tab dialog film setup-flow trace options}

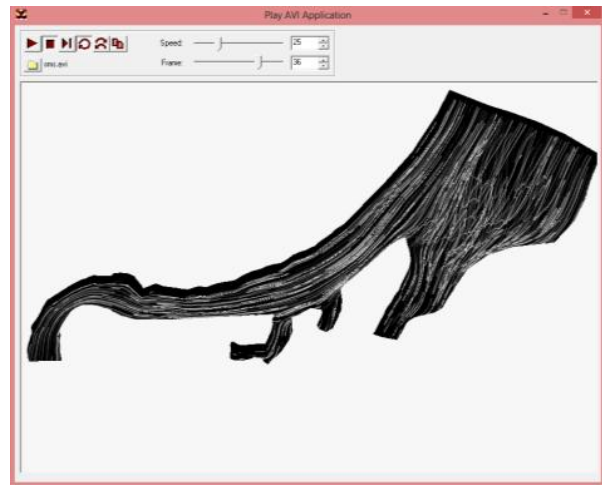

Gambar 32 Bentuk Contoh Trace Aliran

\section{KESIMPULAN DAN SARAN}

\subsection{Kesimpulan}

Dari hasil yang telah dijelaskan sebelumnya, maka dapat diambil kesimpulan antara lain: a. Kecepatan aliran saat pasang terendah pada musim basah adalah $0,00028 \mathrm{~m} / \mathrm{s}$ 0,00287 m/s, dan kecepatan aliran saat pasang tertinggi adalah 0,04367 - 0,4608 $\mathrm{m} / \mathrm{s}$. Kecepatan aliran saat pasang tertinggi pada musim kering adalah $0,02293 \mathrm{~m} / \mathrm{s}-0,27442 \mathrm{~m} / \mathrm{s}$, dan kecepatan aliran saat pasang terendah adalah 0,00029 $\mathrm{m} / \mathrm{s}-0,00194 \mathrm{~m} / \mathrm{s}$. Hal ini diakibatkan karena adanya perubahan arah yang terjadi pada saat itu, sehingga terjadi penurunan kecepatan arus.

b. Berdasarkan dari data yang diperoleh, dapat disimpulkan bahwa nilai kecepatan arus pada saat transisi dari pasang ke surut atau sebaliknyacenderung mengalami penurunan dari nilai sebelumnya. Hal ini disebabkan oleh nilai debit dan nilai elevasi pasang surut yang tinggi.

c. Kecepatan aliran pada bulan November cenderung lebih besar daripada bulan Juli. Karena adanya pengaruh pasang surut dan debit yang besar pada bulan November, meskipun pada simulasi ini angin dianggap konstan, tidak menutup kemungkinan bahwa pengaruh tekanan angin pada pelabuhan mempengaruhi kecepatan aliran.

\subsection{Saran}

Dalam penelitian ini terdapat kekurangan. Untuk ini saran yang ini penulis sampaikan adalah sebagai berikut:

a. Pembuatan mesh modul yang lebih rapi sangat disarankan,

b. Maksimum waktu simulasi yang digunakan lebih dari 1 jam,

c. Perlu eksplorasi yang lebih dalam penggunaan software SMS versi ini dan versi selanjutnya guna memperbaiki hasil output software,

d. Perlu diadakannya penelitian tingkat keandalan pengukuran pola aliran dengan menggunakan program bantu yang lain sehingga didapatkanlah pembanding dalam mempelajari pola aliran pada Pelabuhan Belawan,

e. Penelitian dapat diperluas dengan mempelajari pola sedimentasi pada Pelabuhan Belawan

f. Diperlukan adanya percobaan simulasi untuk mengetahui pola aliran pada pembangunan di pelabuhan agar dapat 
menangani masalah yang berhubungan dengan pola arus.

\section{Daftar Pustaka}

Aquaveo. (2014). SMS Users Manual (v11.1). Aquaveo. Utah.

Asdak, C. (1988). Hidrologi dan Pengelolaan Daerah Aliran Sungai. Gadjah Mada University Press. Yogyakarta.

HTTP://www.pasanglaut.com/as/westindonesia/belawan

Lembaga Penelitian dan Pemberdayaan Masyarakat ITB. (2003). LaporanAkhiran Investigasi Pelabuhan Belawan. Bandung.

P.T. Pelabuhan Indonesia I (PERSERO). (2003). Studi Perilaku Sedimentasi/Siltasi \& Coastal Morphology dalam Rangka

Triatmodjo, B. (2010). Perencanaan Pelabuhan. Beta Offset. Yogyakarta.

Triatmodjo, B. (1999). Teknik Pantai. Beta Offset. Yogyakarta.

US Army, Engineer Research and Development Center. (2005). Users Guide To RMA2WES Version 4.5. Waterways Experiment Station. Brigham Young University 